\title{
Lithospheric Structure of Philippine Sea Plate near the Western End of Ryukyu Subduction Zone and Some of its Tectonic Effects
}

\author{
Chengsung Wang ${ }^{1{ }^{*}}$, Shih-Wei Chuang ${ }^{1}$, Ming-Lung $\mathrm{Li}^{1}$, and Win-Bin Cheng ${ }^{2}$
}

(Manuscript received 15 February 2001, in final form 15 March 2001)

\begin{abstract}
The Ryukyu subduction zone, comprised of the Ryukyu trench, the Ryukyu arc and the Okinawa trough, extends between southern Japan and northern Taiwan. This subduction zone is produced by the northwestward subduction of the Philippine Sea plate beneath the Eurasian plate along the Ryukyu trench. The motion of the Philippine Sea plate is, however, impeded at its northwestern corner by the island of Taiwan, which is reflected in the complicated structure of the Philippine Sea plate at the western end of the Ryukyu subduction zone. Using seismicity, as well as other geophysical and geological data in the Taiwan region, we have investigated the lithospheric structure of the Philippine Sea plate beneath the westhern end of the Ryukyu subduction zone and its tectonic effects.

Although the Philippine Sea plate moves northwestward in general, at its northwestern corner the direction of subduction changes from the northwest to the north. The lithosphere of this northwestern corner of the plate underthrusts and extends westward beneath the island of Taiwan. A western boundary of the lithosphere exists beneath Taiwan. The boundary lies almost along the 121 . $^{\circ} \mathrm{E}$ meridian line. The boundary is migrating westward at a rate of about $6 \mathrm{~cm} / \mathrm{y}$ along with the movement of the Philippine Sea plate. The westward migration of the lithospheric boundary of the plate causes the westward extension of the Okinawa trough, which lags behind the former by about 600,000 years $(-35 \mathrm{~km})$. The initial stage of the formation of the Okinawa trough, in turn, put the whole northern Taiwan area under tensional stress.
\end{abstract}

(Key words: Structure of the Philippine Sea plate, Northern Taiwan area, Seismicity, Morphology, Wave attenuation factor)

\footnotetext{
${ }^{1}$ Institute of Applied Geophysics, National Taiwan Ocean University, Keelung, 202 Taiwan

${ }^{2}$ Department of Visual Communication Design, Jin-Wen Institute of Tectnology, Taipei County, Taiwan

* Corresponding author address: Prof. Chengsung Wang, Institute of Applied Geophysics, National Taiwan Ocean University, Keelung 20224, Taiwan; E-mail: cswang@mail.ntou.edu.tw
} 


\section{INTRODUCTION}

The Philippine Sea plate moves northwestward and subducts beneath the Ryukyu arc and the Okinawa trough on the Eurasian plate along the Ryukyu trench (Fig. 1). The Ryukyu subduction zone, including the Ryukyu trench, the Ryukyu arc and the Okinawa trough, extends from southern Japan to northern Taiwan. It runs northeast-southwest in general. However, near Taiwan, it bends northward and runs east-west. Also, it seems to terminate on the eastern side of the Taiwan island, which is built from the intensive interaction between the Eurasian and Philippine Sea plates. This complicated tectonic structure is mainly due to the fact that the motion of the northwesternmost portion of the Philippine Sea plate is impeded by the island. Therefore, in order to understand the tectonic structure of the northern Taiwan area and its behavior, it is desirable to depict the lithospheric structure of the Philippine Sea plate near the western end of the Ryukyu subduction zone. In this study, using seismological as well as geophysical and geological data, we delineate the lithospheric structure of the subducting Philippine Sea plate near its northwestern corner and examine the interaction between the Eurasian and Philippine Sea plates for the complicated tectonic structure in the northem Taiwan area.

\section{FORMATION OF THE TAIWAN ISLAND}

The Taiwan island has been formed since 4 ma (e.g., Chi et al. 1981; Teng 1990; Lee and Lawver 1994) on the eastern edge of the Chinese continent by the process of arc-continent collision (e.g., Suppe 1984; Teng 1990) or arc-arc collision ( Hsu and Sibuet 1995).

Figure 2 shows the structural provinces of Taiwan and its surrounding offshore region. In Fig. 2, the Coastal Range (province v) in eastern Taiwan plays an important role in the arccontinent collision model (e.g., Barrier and Angelier 1983). It is believed that Coastal Range is a part of both the Luzon arc, and the uplifted part of the forearc basin (e.g., Cheng et al. 1996, 1998), which has formed from the eastward subduction of the South China Sea lithosphere beneath the Philippine Sea plate along the Manila trench. In the arc-continent collision model, the Luzon arc has been colliding with the Eurasian plate, resulting in the growth of the western foothills and Central Range of Taiwan through deformation of strata and basement rocks of the Asian continental margin. The suture zone of the collision (the Longitudinal Valley of eastern Taiwan; province iv in Fig. 2) lies along the length of Taiwan.

Based on the P-wave velocity structure derived from seismic refraction experiments in the northeastern Taiwan area, Cheng et al. (1996) found that the eastern flank of the Central Range in central Taiwan (designated by EFCR in Fig. 2) and the western end of the Ryukyu arc have similar characteristics in seismic velocity and speculated that they are parts of the same tectonic unit. Delineating the Luzon arc from the magnetic anomaly, Shyu et al. (1996) found that the Luzon arc extends northward on the eastern side of the Coastal Range and that northern Coastal Range is now a part of the Luzon arc. From a 3-D P-wave velocity study based on signals from earthquakes and air gun shots in the southeastern area of Taiwan, Cheng et al. (1998) showed a zone of relatively lower P-wave velocity near the surface, between the Luzon arc and the eastern coastline of Taiwan. In the arc-arc collision model (Hsu and Sibuet 


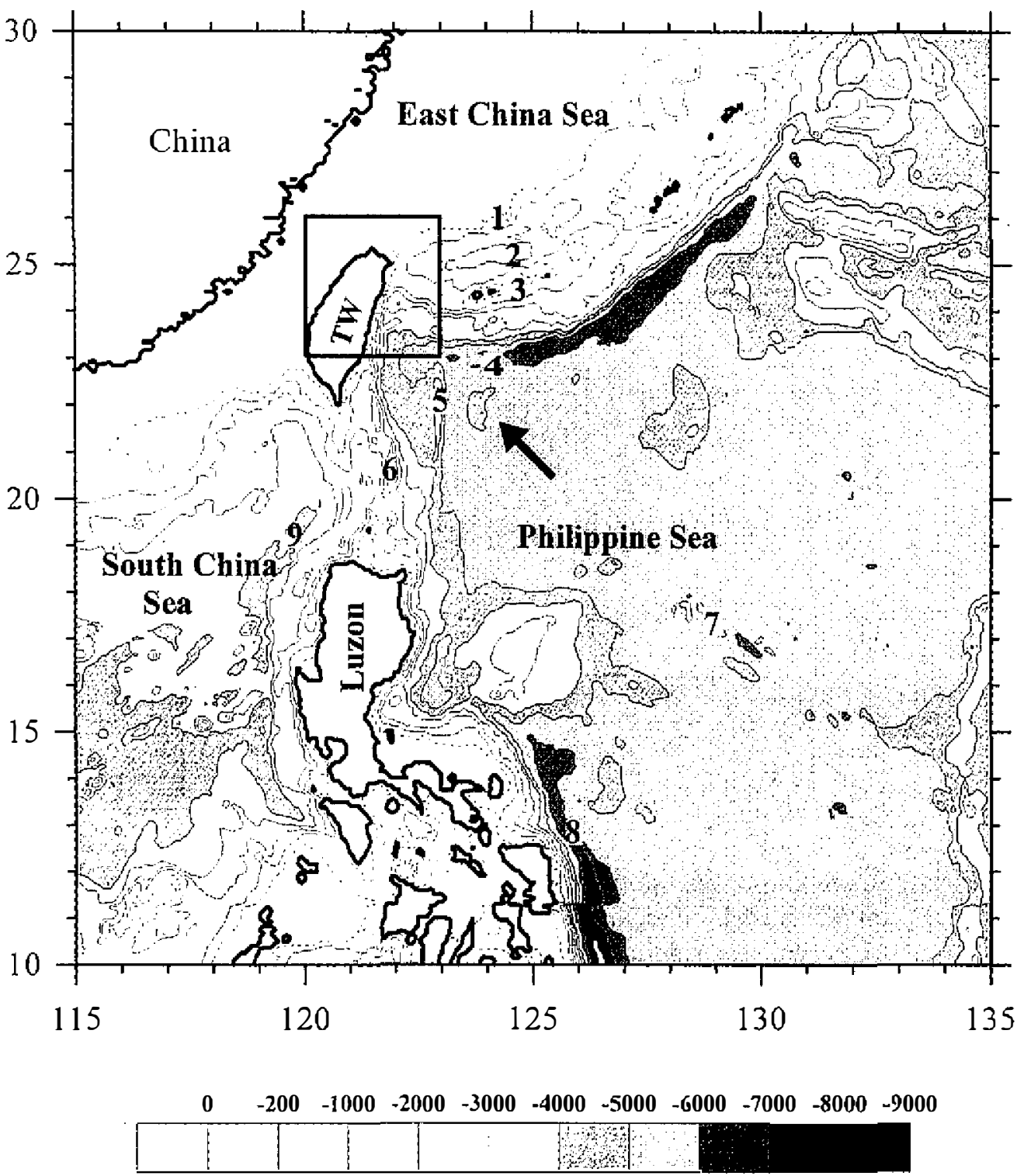

Fig. I. Bathymetry and tectonic units in the Ryukyu-Taiwan-Philippine region. TW: Taiwan; 1. Continental slope of East China Sea; 2. Okinawa trough; 3. Ryukyu island arc; 4. Ryukyu trench; 5 . Gagua ridge; 6 . Luzon island arc; 7. Central Basin ridge of West Philippine Basin; 8. Philippine trench; 9. Manila trench. The arrow to the southeast of Taiwan shows the general direction of movement of the Philippine Sea plate. The box in the northern Taiwan area is the study area of this paper. The contour lines of water depth are in 1,000 meters. 


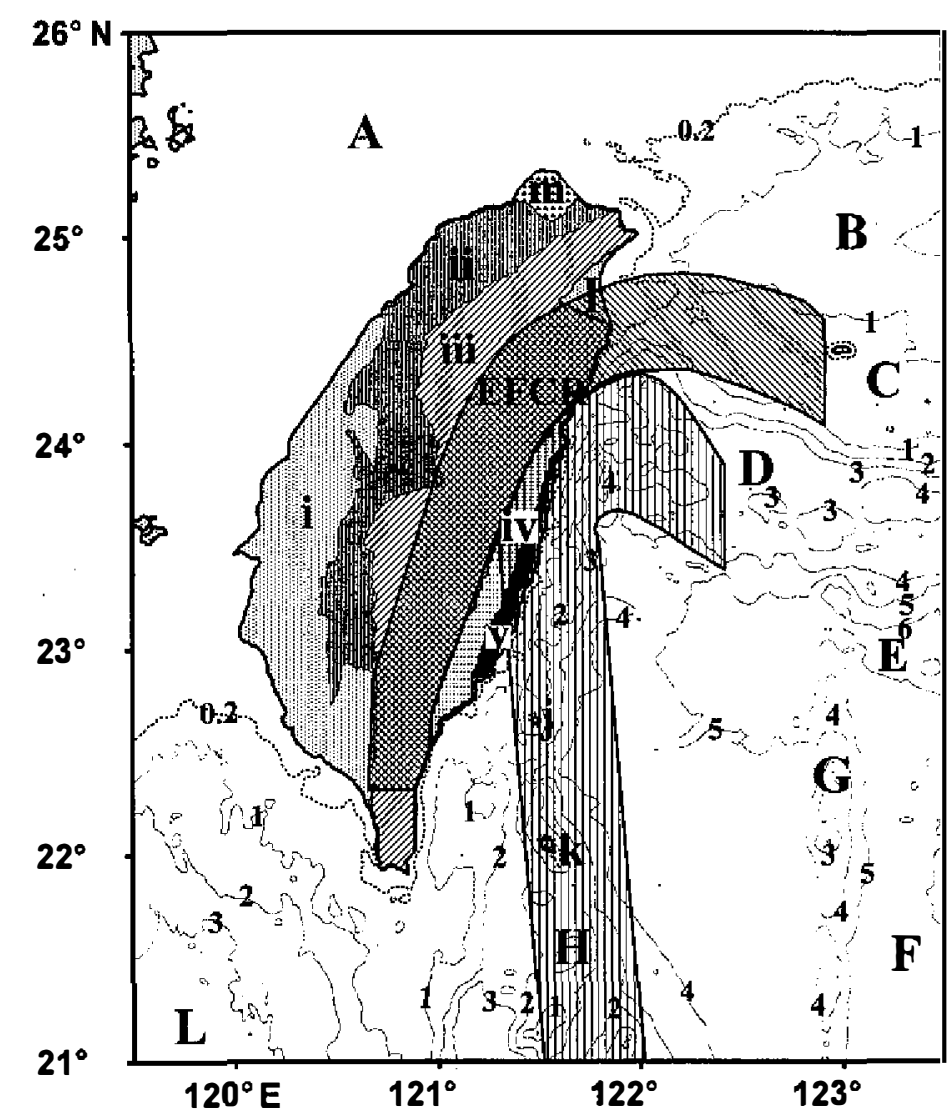

Fig. 2. Structural provinces on the Taiwan island (Ho 1986, 1988) and its surrounding offshore region. The two belts on the map are Ryukyu arc and Luzon arc newly defined by Cheng et al. (1996) and Shyu et al. (1996). The bathymetric data are from Liu et al. $(1996,1998)$. A: continent shelf of East China Sea; B: Okinawa trough (backarc basin of Ryukyu arc); C: Ryukyu arc; D: Nan-ao Basin (forearc basin of Ryukyu arc); E: Ryukyu trench; F: Philippine Sea plate; G: Gagua ridge; H: Luzon arc; I: Ilan plain; L: Manila trench; $\mathrm{j}$ : Lutao (island); $\mathrm{k}$ : Lanhsu (island); $\mathrm{m}$ : Tatun vocano; i: Western Coastal Plan; ii: West Foothills; iii: Central Range; iv: Longitudinal Valley; v: Coastal Range; EFCR: Eastern flank of Cenral Range. The numbers on the bathymetric contour lines are the depth in 1,000 meters.

1995), the Luzon arc has been colliding with the Ryukyu arc, lying on the edge of the Eurasian plate. Shyu et al. (1996) and Cheng et al. $(1996,1998)$ interpreted that the Coastal Range extends northward to $24.2^{\circ} \mathrm{N}$ and that the arc-arc collision is direct north of $23.5^{\circ} \mathrm{N}$, and is indirect ( with the deformed and uplifted sediment layers of the southern Coastal Range and its southern extension between the Luzon arc and the eastern coastline of Taiwan as buffer) south 
of $23.5^{\circ} \mathrm{N}$, as demonstrated by the two belts in Fig. 2 .

Either the arc-continent collision model or the arc-arc collision model mentioned above only describes the surface or subsurface geological phenomena of the Taiwan orogeny. The Taiwan orogeny and the formation of the Ryukyu subduction zone are, however, closely related to the lithospheric structure of the Philippine Sea plate in the Taiwan area.

\section{WADATI-BENIOFF ZONE AND THE WESTERN BOUNDARY OF THE SUBDUCTING LITHOSPHERE}

In 1990, two telemetered earthquake monitoring networks in Taiwan were incorporated into the Central Weather Bureau Seismological Network (CWBSN), a dense seismological observation network with more than seventy stations operated by the Seismological Observation Center, Central Weather Bureau of Republic of China (Taiwan). At the same time, the associated software and hard ware for recording and locating earthquakes were upgraded greatly. Since then, the dynamic range of monitoring capacity and precision of earthquake location in the Taiwan region have improved. Here we use seismicity maps and hypocentral profiles, based on earthquakes recorded by the CWBSN since 1991, to delineate the Wadati-Benioff Zone associated with the subducting Philippine Sea plate at the western end of the Ryukyu subduction zone.

Figure 3 shows the distribution of earthquake epicenters in the Taiwan region and zones of earthquakes used for plotting the hypocentral profiles. Figures 4 and 5 show hypocentral profiles in the northern Taiwan area in the N-S and E-W directions, respectively. By comparison of these profiles with the seismicity maps in Fig. 3, it can be seen that most earthquakes occur at depths of less than $40 \mathrm{~km}$, including those in the seismic belts.

Earthquakes in the northern Taiwan area which are deeper than $40 \mathrm{~km}$ (Figs. 4 and 5) mostly fall into the Wadati-Benioff Zone associated with the subduction of the Philippine Sea plate. In Fig. 4, the hypocentral profiles in the N-S direction show that to the east of $121.5^{\circ} \mathrm{E}$ (the right column) the Wadati-Benioff Zone is clear. To the west of $121.5^{\circ} \mathrm{E}$ (the left column), the earthquakes deeper than $40 \mathrm{~km}$ are much fewer and scattered. In Fig. 5, the hypocentral profiles show that most earthquakes fall into two groups. The top group includes those earthquakes shallower than $40 \mathrm{~km}$. The bottom group is the Wadati-Benioff Zone which is situated deeper and deeper when the hypocentral profiles move to the north. From the hypocentral profiles in Figs. 4 and 5, it can be seen clearly that, in general, the Wadati-Benioff Zone exists to the east of $121.5^{\circ} \mathrm{E}$, though there are still some fine structures in the zone.

From the location and attitude of the Wadati-Benioff Zone shown in Figs. 4 and 5, we interpret that the Philippine Sea plate subducts northward in the Taiwan region along the Ryukyu trench, with the meridian line of $121.5^{\circ} \mathrm{E}$ as the present westem boundary of the active subducting lithosphere (Fig. 6). Tsai et al. (1977) used this meridian line to separate two seismic areas of different tectonic significance in the Taiwan region: the Northeastern Seismic Area and the Westem Seismic Area. This westem boundary line of the northward-subducting plate in the Taiwan region intersects the eastern coastline of Taiwan at $23.5^{\circ} \mathrm{N}, 121.5^{\circ} \mathrm{E}$, where Shyu et al. (1996) separated the direct collision and the indirect collision of the Luzon arc against the Ryukyu arc (Fig. 2). 


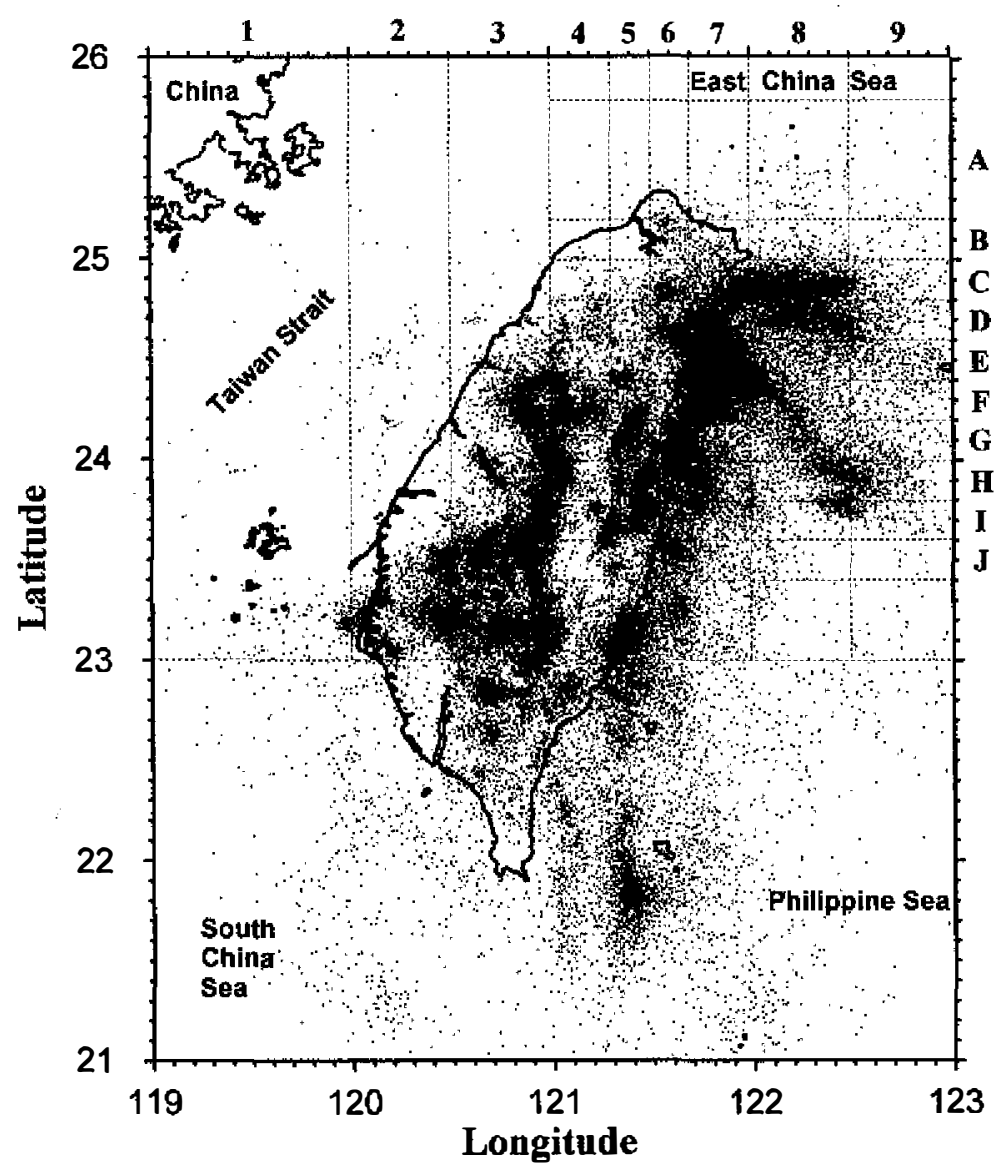

Fig. 3. Epicenters of earthquakes in the Taiwan region recorded and located during 1991-2000 by Seismological Observation Center, Central Weather Bureau of Republic of China (Taiwan). The strips of space with labels show the locations of hypocentral profiles in Figs. 4 and 5.

According to Seno (1977) and Seno et al. (1993), the speed of the northwestward movement of the Philippine Sea plate is about $7 \mathrm{~cm} / \mathrm{y}$ toward Taiwan. The velocities of Lanhsu and Lutao GPS stations on the Luzon arc relative to the Paisha GPS station on one of the Penghu islands (Fig. 7) in the western offshore area of Taiwan (Yu et al. 1997) shows that the Philippine Sea plate is moving $N 50^{\circ} \mathrm{W}$ at a speed of about $8 \mathrm{~cm} / \mathrm{y}$ with respect to Eurasia. Calculating from the velocity vector of the plate movement of Yu et al. (1997), we obtain western and northern components for the velocity of the Philippine Sea plate in the Taiwan region. These are about $6 \mathrm{~cm} / \mathrm{y}$ and $5 \mathrm{~cm} / \mathrm{y}$, respectively. Therefore, the western boundary of the subducting lithosphere beneath the Taiwan island along the meridian line of $121.5^{\circ} \mathrm{E}$ is migrating westward at a speed of about $6 \mathrm{~cm} / \mathrm{y}$.

\section{DOUBLE PLUNGING OF THE LITHOSPHERE}

The geomagnetic study by Shyu et al. (1996) showed that the Luzon arc subsides toward the north along with the Philippine Sea plate and meets the eastern coastline of Taiwan at $23.5^{\circ} \mathrm{N}$. Geodetic data from Yu et al. (1997) show that most of the crustal shortening on Taiwan occurs to the south of $23.6^{\circ} \mathrm{N}$, i.e., in the southern half of the island (Fig. 7); north of 


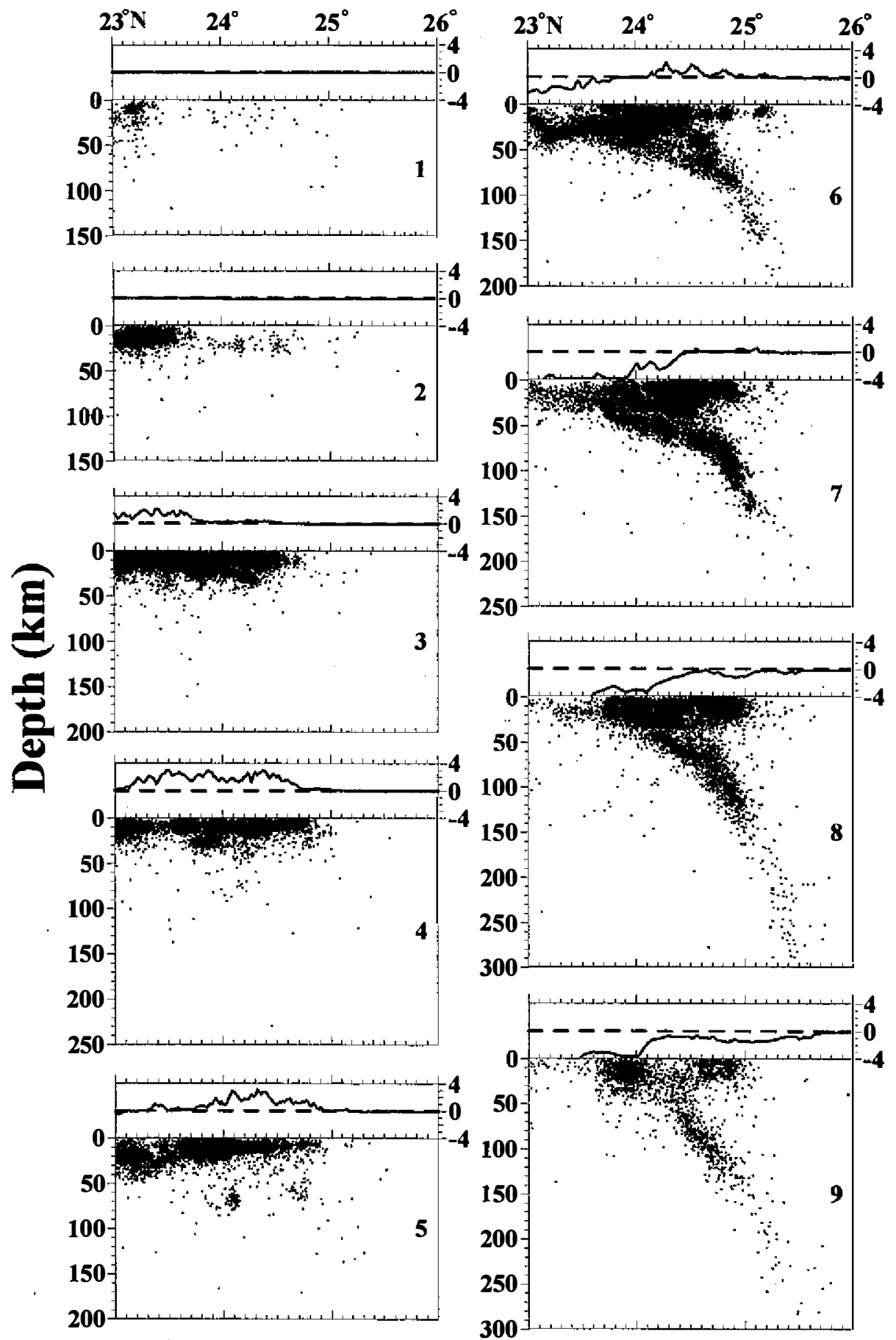

Fig. 4. The N-S directional hypocentral profiles in the northern Taiwan area. See Feg. 3 for the locations of the profilers. 

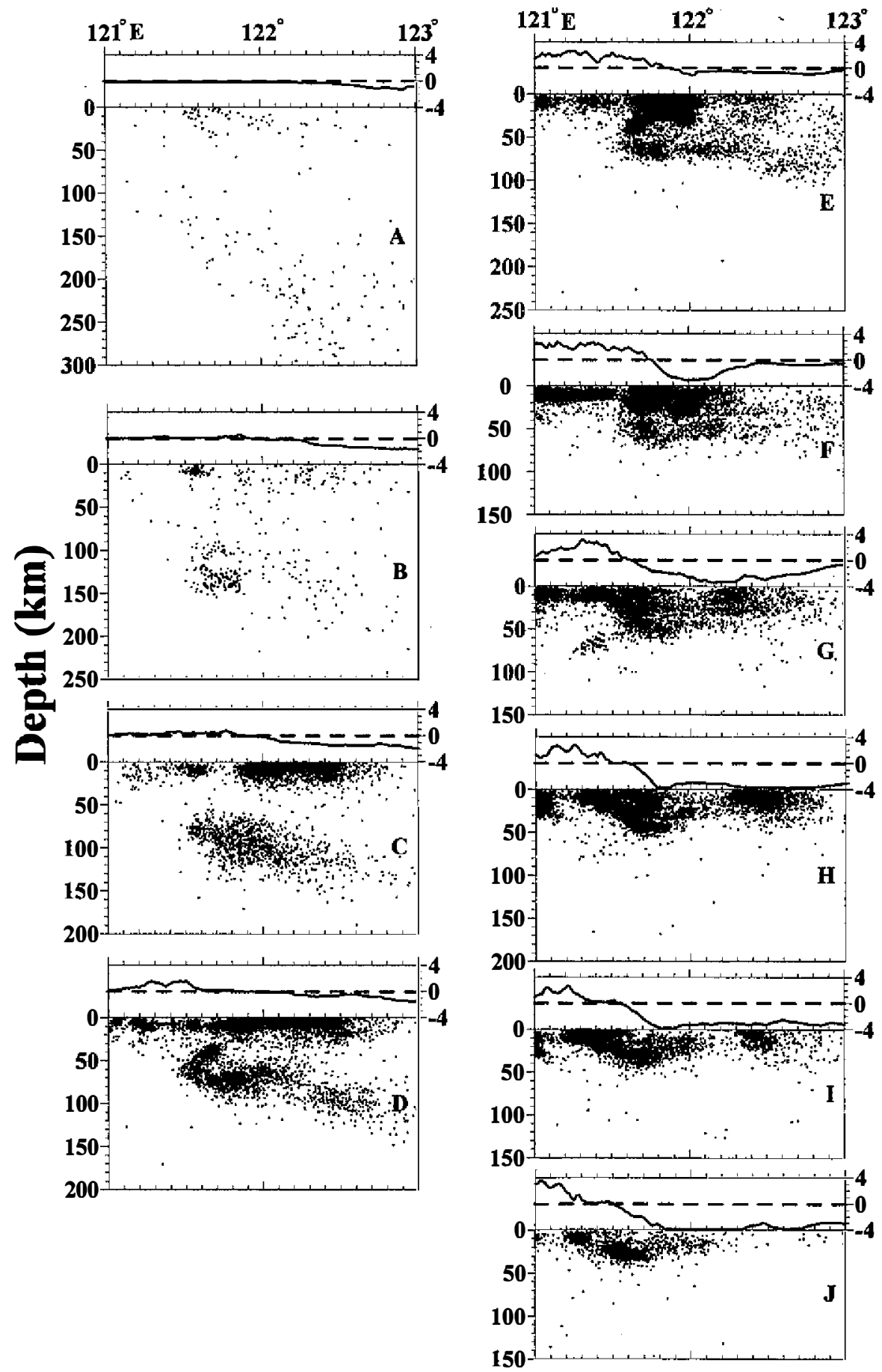

Fig. 5. The E-W directional hypocentral profiles in the northern Taiwan area. See Feg. 3 for the locations of the profilers. 


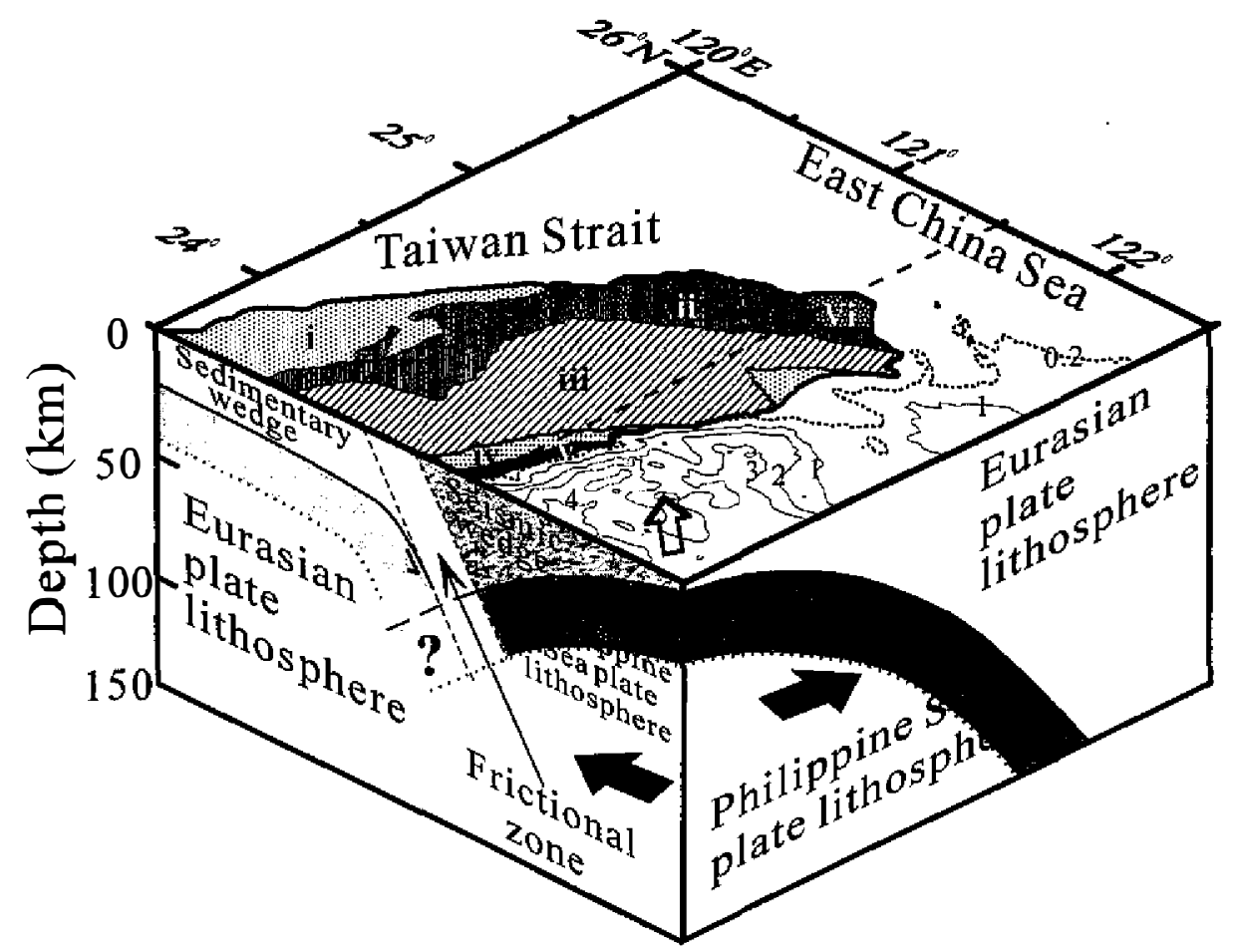

Fig. 6. Model of double lithospheric plunging of the Philippine Sea plate. The shaded zones in the north-south profile is the Wadati-Benioff Zone representing the upper part of the subducting lithosphere. The east-west tectonic profile is revised from Wang et al. (2000). This profile shows the interaction between the Eurasian and the Philippine Sea plates, including locations of the seismic wedge (Wang et al. 2000), the sedimentary wedge above the Eurasian plate, and a frictional zone between the two plates.

$23.6^{\circ} \mathrm{N}$, crustal shortening in the NW-SE direction is not obvious. From the location of the Wadati-Benioff Zone shown in the hypocentral profiles in Fig. 4, and the geomagnetic and GPS data discussed above, it is obvious that the northward subduction of the Philippine Sea plate along the Ryukyu trench near eastern Taiwan starts south of $23.5^{\circ} \mathrm{N}$ (Figs. 6 and 7).

From the Wadati-Benioff Zone shown in Fig. 4, it is obvious that near the eastern coastline of Taiwan, this seismic zone (the lowest zone) is not bending smoothly downward to the north; instead, it has intrinsic structure and seems to be composed of several segments with different slopes. It may be associated with the NW striking left-lateral faultings in the lithosphere (Wang 1988; Wang and Wu 1991), near the western lithospheric boundary, caused by the horizontal lithospheric bending of the Philippine Sea plate due to the impediment of the northwestward motion of the plate by the Eurasian plate (Wang 1982; Wang 1988; Wang and Wu 1991; also Fig. 6). It may also be associated with the formation process of the Ryukyu subduction zone. The cause and effect of this complicated structure of the lithosphere in the eastern Taiwan area still need further study. 


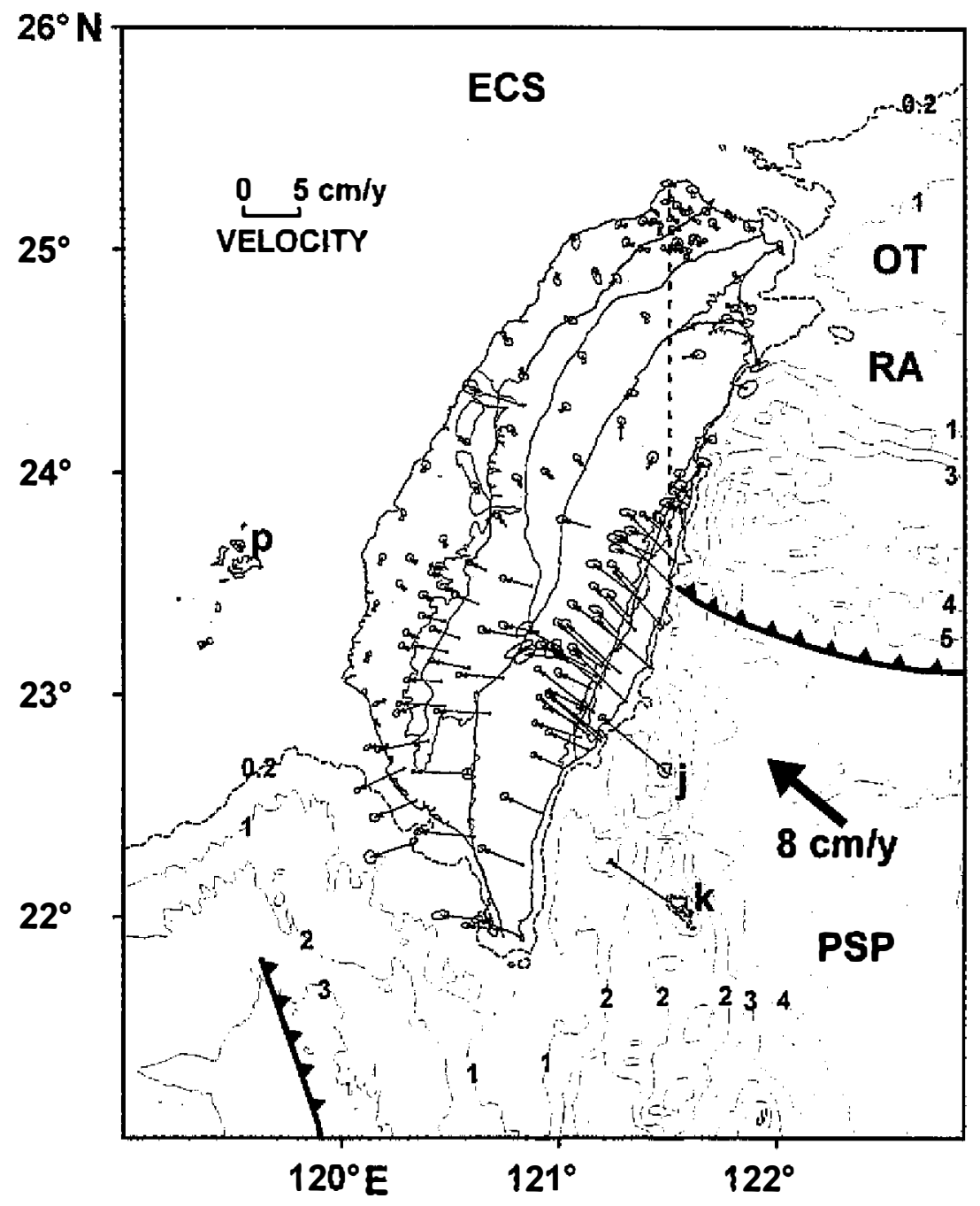

Fig. 7. Velocities of GPS stations in the Taiwan region relative to Paisha station (designated by A) west of Taiwan (Yu et al. 1997). The 95\% confidence ellipse is shown at the tip of each vector. In the bsckground, the contours of water depth, the tectonic units and the two subduction systems (solid lines with solid rianges) are shown. The motion speed of the Philippine Sea plate near Taiwan with respect to Eurasial is estimated from velocity vectors of GPS stations on two islands southeast of Taiwan, Lutao and Lanhsu (designated by B and C, respectively). Numbers on contour lines of water depth are in 1000 meters. The dashed line along the median line of $121.5^{\circ} \mathrm{E}$ is the surface projection of the western lithospheric boundary of the Philippine Sea plate. ECS: East China Sea; OT: Okinawa trough; RA: Ryukyu arc; PSP: Philippine Sea plate. 
From the E-W directional hypocentral profiles shown in Figs. 5 and 8, it is clear that, near Taiwan, the northward-subducting lithosphere of the Philippine Sea plate also underthrusts and extends westward beneath eastern offshore area of Taiwan and northern Taiwan. This lithospheric underthrusting may be caused by the mountain building of Taiwan island, because the island rides on the meeting zone of the Euarsian and Philippine Sea plates along the meridian line of $121.5^{\circ} \mathrm{E}$ (Fig. 6).

The forearc basin (Fig. 2) of the Ryukyu subduction zone east of the Gagua ridge along the meridian line of $123^{\circ} \mathrm{E}$ runs northwest-southeast, and the westward underthrusting of the Philippine Sea plate starts from this forearc basin. The westward lithospheric underthrusting is most obvious near the latitude of $24^{\circ} \mathrm{N}$, near which the Chi-Chi earthquake of Richter magnitude $M_{L} 7.3$ occurred on September 21, 1999, which is a episode of the vivid mountain building of the Taiwan island due to the pushing of the Philippine Sea plate on the Chinese conti-
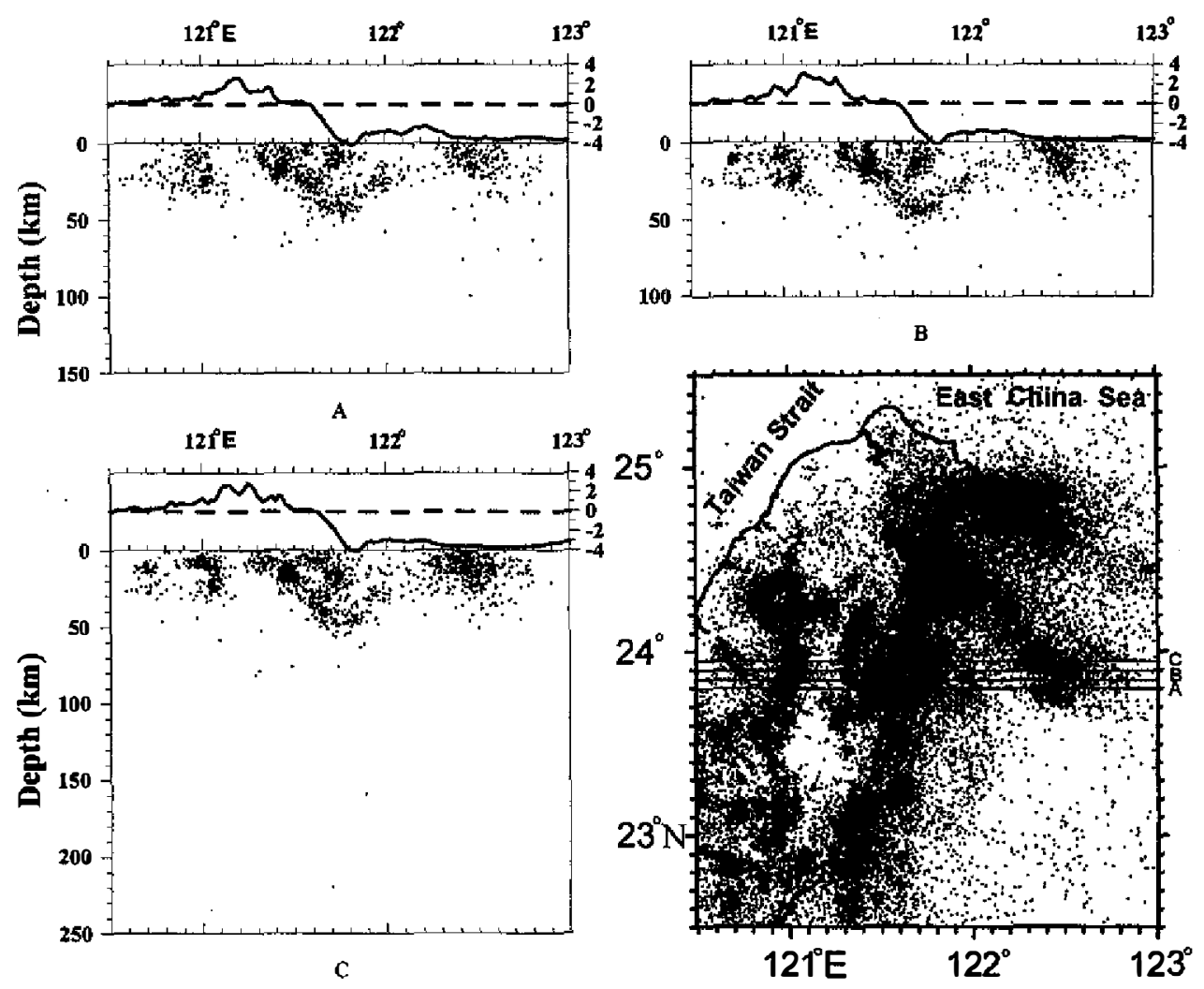

Fig. 8. The east-west hypocentral profiles across the Taiwan island near the latitude of $24^{\circ} \mathrm{N}$, near which the Chi-Chi earthquake with Richter magnitude $M_{L} 7.3$ occured in central-western Taiwan on September 21, 1999. These profiles clearly show the westward lithospheric underthrusting of the Philippine Sea plate, exhibited by the attitude of the Wadati-Benioff Zone (the lowest seismic zone). 
nental shelf edge (e.g., Wang et al. 2000). This phenomenon of the westward lithospheric underthrusting disappears when the forearc basin terminates against the eastern coastline of Taiwan at about $24.4^{\circ} \mathrm{N}$. The relationship between the phenomenon of the lithospheric underthrusting and the existence of the forearc basin of the Ryukyu subduction zone is intriguing.

\section{WESTWARD EXTENTION OF OKINAWA TROUGH}

The Okinawa trough is a part of the Ryukyu subduction zone, which is running between southern Japan and Taiwan and is convex toward the southeast (Fig. 1). The westem edge of the trough lies at the northeastem coastline of Taiwan. It has been found that at its westem end near northeastern Taiwan; the formation of the Okinawa trough has been propagating westward along the whole width of about $100 \mathrm{~km}$ (e.g., Wang et al. 2000). In other words, the southwestern part of the Okinawa trough is not formed simultaneously, but has been growing from the east to west.

The northward subduction of the plate causes the opening of the Okinawa trough in the northern Taiwan area. Since the Philippine Sea plate moves northwestward, the migration of the western boundary of the subducting lithosphere, along with the movement of the plate, initiates the westward propagation of the opening of the Okinawa trough towards northern Taiwan. The rate of the westward extension of the Okinawa trough should be the same as that of the migration of the western lithospheric boundary. The opening of the western part of Okinawa trough started about $2 \mathrm{Ma}$ (e.g., Lee et al. 1980; Sibuet et al. 1998). A volcanic seamount situated at $123.1^{\circ} \mathrm{E}, 25.2^{\circ} \mathrm{N}$ (designated " $\mathrm{x}$ " in Fig. 9), near the northern edge of the Okinawa trough, is believed to have been created about $2 \mathrm{Ma}$, at the beginning of the formation of the Okinawa trough; it was created in the center of the Okinawa trough, and then migrated to its present position due to the spreading of the Okinawa rough (Sibuet et al. 1998). Kueishan Tao (designated "y" in Fig. 9), a 7000-year-old volcanic island (Chen et al. 1998) situated at $121.95^{\circ} \mathrm{E}, 24.8^{\circ} \mathrm{N}$ off the Ilan plain, represents the western end of the inner volcanic arc of the Ryukyu subduction zone. Using the distance between the volcanic seamount and island, and the difference in age, we calculate an approximate value of $6.4 \mathrm{~cm} / \mathrm{y}$ for the average extension rate of the Okinawa trough. This value confirms the extension rate, estimated from GPS data, of about $6 \mathrm{~cm} / \mathrm{y}$.

The westward migration of the opening and formation of the Okinawa trough causes the slumping and collapsing of material on the continental shelf-slope area toward the center of the trough. Apart from the morphological phenomena in the northeastern of fshore area of Taiwan described by Wang et al. (2000), Figure 10 also shows the collapsing and slumping phenomena in the northern offshore area of Taiwan. The material in this area has been transported toward the Okinawa trough mainly through the Chilung Valley and Mien-hua Canyon (Fig. 9). Material on the sides of these two channels slumps or collapses toward the channels. In northern Taiwan there are several faults striking NE. Traces of these faults extend northeastward in the northern offshore area of Taiwan morphologically (Fig. 10). At present, normal faulting appears prevalent along these fault. The material seems to move toward the center of the Okinawa trough northeast of Taiwan. Also, some small lots are sinking directly (deeper than the surrounding area), such as the small area denoted by "a" in Fig. 10. These indicate that 


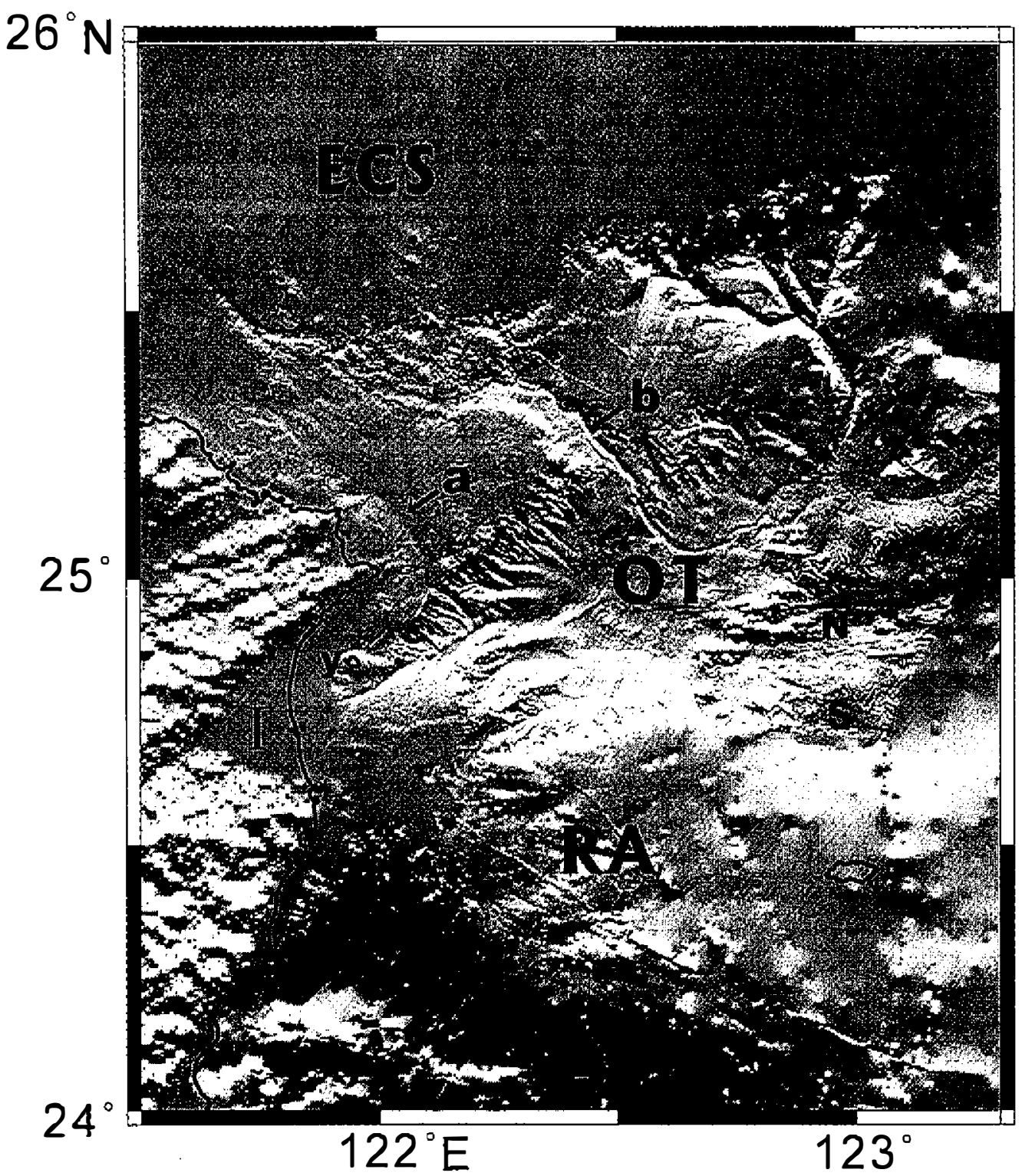

Fig. 9. Morphology of the western end of the Ryukyu subduction zone. The three small arrows, a, b and c, on the continental shelf/slope show the locations of the Chilung Valley, the Mien-hua Canyon and the North Mien-hua Canyon. See Wang et al. (2000) for detailed description. ECS: East China Sea; OT: Okinawa trough; RA: Ryukyu arc; I: Ilan plain; N: Northern central graben; S: Southern central graben; $x, y$ : volcanic seamount and islet (the Kueishan islet) used for calculating the rate of westward extension of the Okinawa trough. 
the northern offshore area of Taiwan is under tensional stress.

From both the focal mechanisms in northern Taiwan, the slumping and collapsing phenomena in the northeastern offshore area of Taiwan (Wang et al. 2000) and the above-discussed morphology in the northern offshore area of Taiwan, we can conclude that the whole northern Taiwan area is presently under tensional stress. This is most probably caused by the initial formation of the Okinawa rough due to the westward lithosphere migration of the Philippine Sea plate beneath the western end of the Ryukyu subduction zone.

\section{DISCUSSION}

Several points concerning the Okinawa trough, the western boundary of the subducting Philippine Sea plate-and the stress status are worth noting. (1) The morphology (Fig. 9), suggests that the traditionally recognized Okinawa trough reaches, at most, the eastern coastline of the Ilan plain in eastern Taiwan. (2) Judging from the Wadati-Benioff Zone (Figs. 4 and 5), the active subducting lithosphere of the Philippine Sea plate extends westward to the meridian line of $121.5^{\circ} \mathrm{E}$. (3) The morphology of the continental shelf-slope area of the East China Sea suggests the slumping and collapsing of material, and the sinking of the sea floor, reach 121 . $5^{\circ} \mathrm{E}$ in the northern offshore area of Taiwan. (4) The focal mechanisms in northern Taiwan indicate tensional stress to the north of about $24.5^{\circ} \mathrm{N}$ (Wang et al. 2000). (5) There are scattered hypocenters of earthquakes deeper than $40 \mathrm{~km}$ in northem Taiwan west of the $121.5^{\circ} \mathrm{E}$ meridian line (the western boundary of the subducting lithosphere of the Philippine Sea plate) (Figs. 4 and 5).

From (1) and (2) above, we can conclude that the subducting lithosphere of the Philippine Sea plate advances westward about $35 \mathrm{~km}$ before the opening of the traditionally-recognized Okinawa rough. From (2) and (3), we know that the slumping, collapsing and sinking of the sea floor are associated with the presence of the subducting lithosphere. From (2), (4) and (5), we know that the tensional stress and the scattered deep hypocenters of earthquakes advance well before the western lithospheric boundary of the Philippine Sea plate. The physical-chemical interpretation of these points is desired.

In order to provide information on the strength of material beneath the Taiwan area, Cheng (2000) derived a three-dimensional seismic attenuation structure from the seismic intensity data on Taiwan. The attenuation of the $S$ wave can be presented by a parameter $Q_{s}$, defined in terms of the fractional loss of energy per cycle, $-\Delta E / E: 2 \pi / Q_{s}=-\Delta E / E$. In this way, $1 / Q_{s}$ can be called the attenuation factor of the $S$ wave; its value represents the degree that the material is softened or weakened in the Earth, mainly due to the presence of heat or water. Figure 11 shows the distribution of the attenuation factor $1 / Q_{s}$ of a layer $49-74 \mathrm{~km}$ deep in the Taiwan area. We can see that the attenuation factor of the material beneath the whole Okinawa trough is higher than the rest of the Taiwan area, indicating that seismic waves will experience more serious attenuation when they travel through the space beneath the Okinawa trough. In the northern Taiwan area, the higher value of the attenuation factor of this layer may indicate the location of material that has been softened, weaken or become half-molten due to the subduction of the Philippine Sea plate. It is very interesting to notice that the zone of high attenuation factor extends westward at least to the $121.5^{\circ} \mathrm{E}$ meridian line, i.e., the western lithospheric 


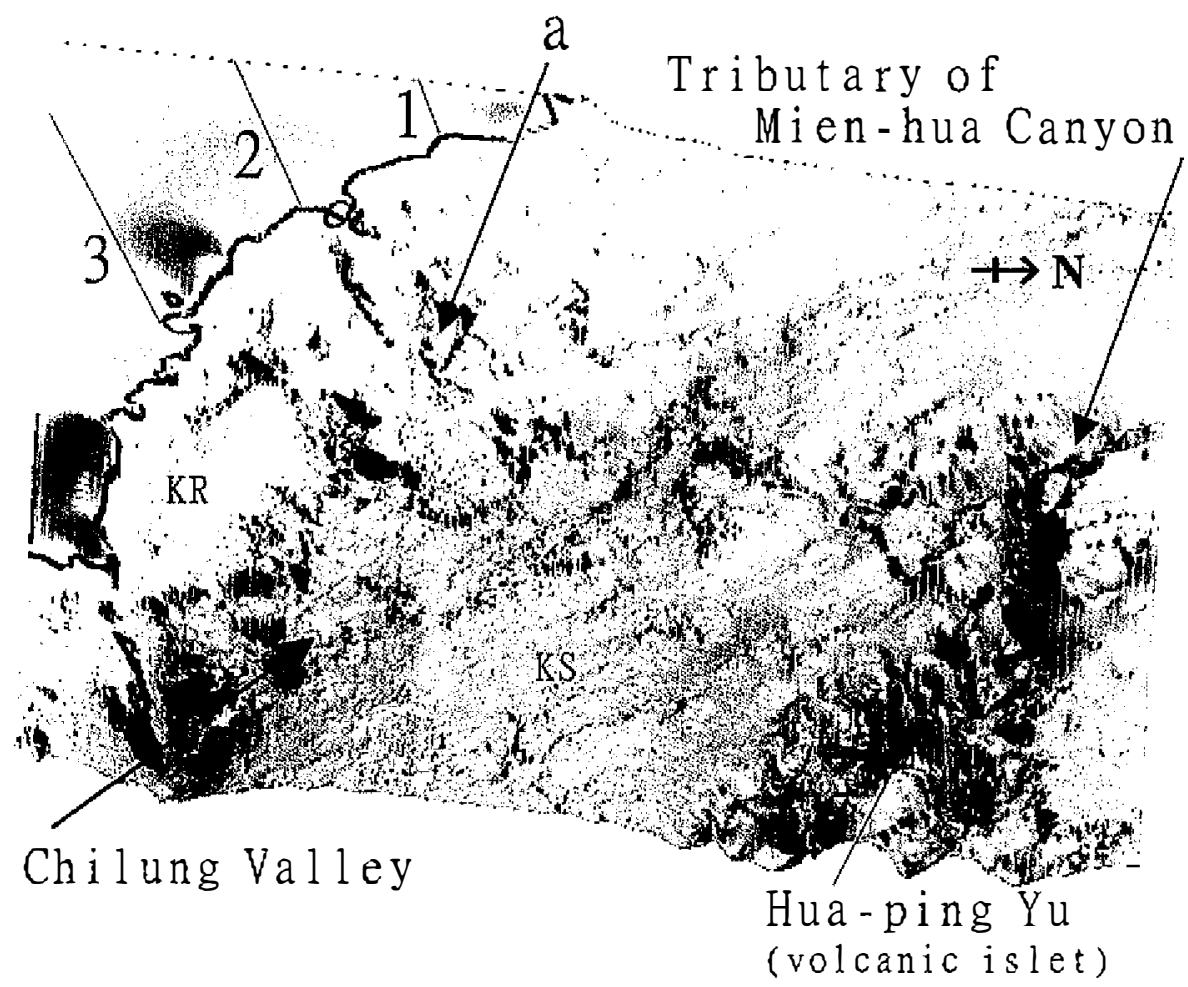

Fig. 10. Shaded topography of the northern offshore area of Taiwan. This figure show some morphological evidence of tensional stress.

boundary of the northward-subducting Philipping Sea plate. We can conclude that the physi$\mathrm{cal}$ and chemical processes that weaken the material above the subducting lithosphere have been in progress since the presence of the subducting lithosphere. Another conclusion drawn from Fig. 11 is that the morphological phenomenon of collapsing and sinking of the sea floor in the northern offshore area of Taiwan is associated with the physical-chemical processes in progress, since this phenomenon has advanced westward to the $121.5^{\circ} \mathrm{E}$ meridian line.

\section{CONCLUSIONS}

Based on seismicity, and geophysical and geological data, we have examined in this study the lithospheric structure of the northwesternmost portion of the Philippine Sea plate which is beneath the western end of the Ryukyu subduction zone (including the Ryulyu mench, Ryukyu arc and the Okinawa trough). and its effects on the tectonic structure in the northern Taiwan area. Following are our main conclusions:

(1) The Philippine Sea plate moves generally northwestward. However, it subducts northward at its northwestern corner due to the impediment of Taiwan island, with its western boundary almost being along the $121.5^{\circ} \mathrm{E}$ meridian line, beneath northern Taiwan. 


\section{Layer $5 \quad 49-74 \mathrm{~km}$}

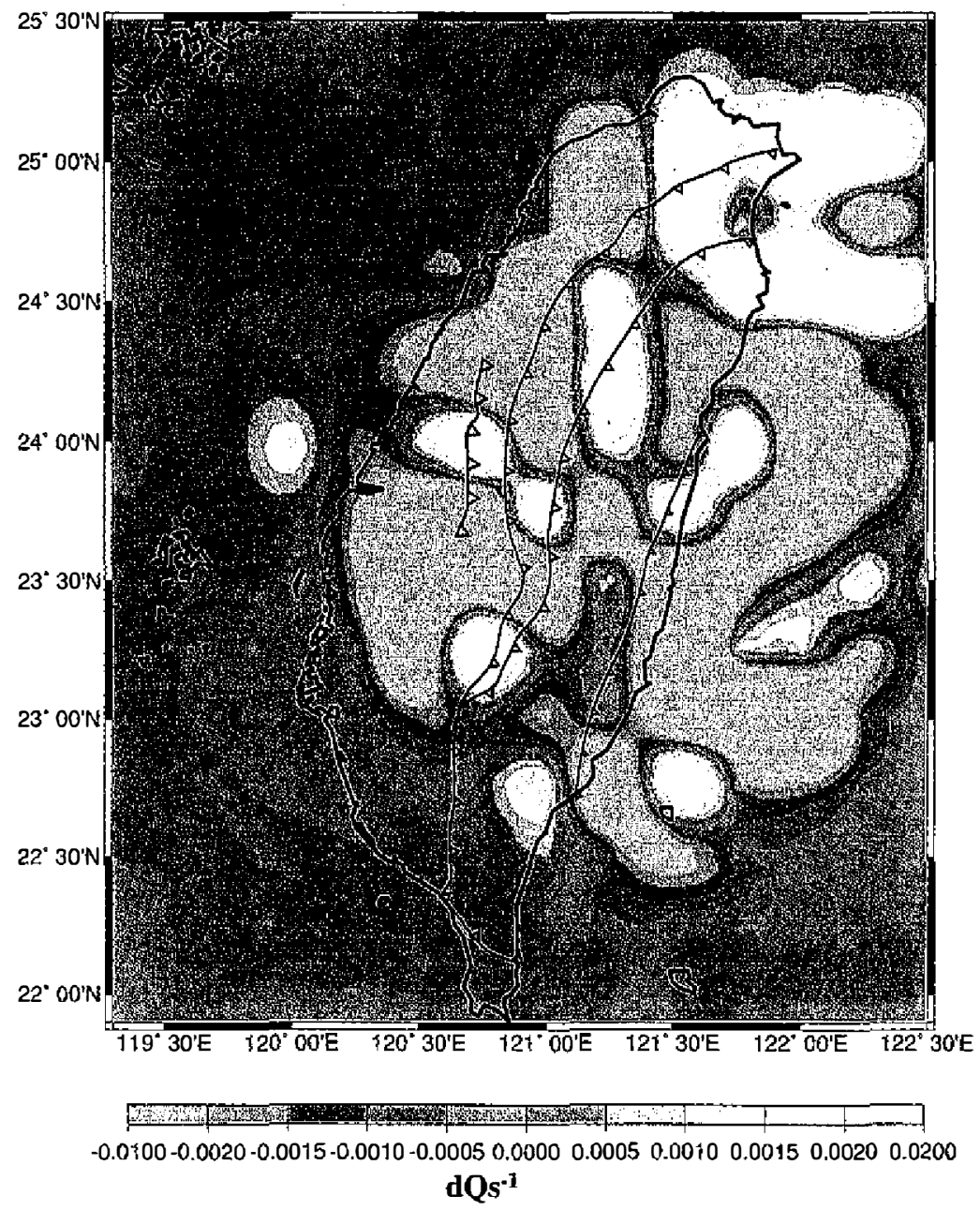

Fig. 11. Distribution of the values of the attenuation factor $1 / \mathrm{Q}_{\mathrm{s}}$ of a layer $49-74$ $\mathrm{km}$ in depth beneath the Taiwan area. A zone of consistent high value of the attenuation factor can be clearly seen in the whole Okinawa trough area.

(2) Moving at a rate about $6 \mathrm{~cm} / \mathrm{y}$ along with the movement of the Philippine Sea plate, the western boundary results in the westward extension of the Ryukyu subduction zone, most apparently in the Okinawa trough. The westward extension of the Okinawa trough causes the slumping and collapsing of material in the continental shelf-slope area in the northern and northeastern offshore areas of Taiwan, and puts the whole northern area of Taiwan under tensional stress.

(3) Comparing the location of the western end of the traditionally-recognized Okinawa trough, to the east of the Ilan plain in northeastern Taiwan, with that of the western lithospheric 
boundary of the subducting Philippine Sea plate, it is obvious that the opening of the Okinawa trough is about $35 \mathrm{~km}$ or 600,000 years behind the westward advancement of the subducting lithosphere of the Philippine Sea plate. However, according to seismic tomographic study, the softened material caused by the subduction of the Philippine Sea plate beneath the Okinawa trough extends westward at least to the western lithospheric boundary of the plate. The difference might have implications for formation processes of the Okinawa trough.

(4) The impediment of Taiwan island makes the northwestern corner of the Philippine Sea plate in the northeastern Taiwan area plunge doubly - it not only subducts northward, but also underthrusts westward. The Watadi-Benioff zone, which dips to the north and represents the upper part of the subducting lithosphere, is composed of several segments of different slope. This may imply complicated processes in the formation of the Ryukyu subduction zone, and deformation or faulting of the lithosphere near its western boundary.

Acknowledgements This study is supported by National Science Council of Republic of China (Taiwan) under grant number NSC 89-2921-M-019-001-EAF. We are grateful for the Seismological Observation Center, Central Weather Bureau, Ministry of Transportation and Telecommunications of the Republic of China (Taiwan) for providing us with the seismicity data used in this study. We also wish to thank Dr. Gwo-Shyh Song of the Institute of Oceanography, National Taiwan University for bathymetric data on the northern offshore area of Taiwan, collected in his many cruises for the KEEP program.

\section{REFERENCES}

Chen, Y. K., W. H. Wu, T. Q. Liu, and C. H. Chen, 1998: Kueishan Tao: the holocene volcanic island. Proc. Annual Meeting of Geoglocial Society of China (Taiwan), 104-105.

Cheng, W.B., 2000: Three dimensional seismic attenuation structrre beneath the Taiwan area by inversion of seismic intensity data. Proc. of the $8^{\text {th }}$ Symposium on Geophysics in Taiwan, 370-379.

Cheng, W. B., C. Wang, and C. T. Shyu, 1996: Crustal structure of the northeastern Taiwan area from seismic refraction data and its tectonic implication. TAO, 7, 467-487.

Cheng, W. B., C. Wang, C. T. Shyu, and T. C. Shin, 1998: A Three-dimensional Vp model of the southeastern Taiwan area and its tectonic implications. TAO, 9, 425-452.

Chi, W. R., J. Namson, and J. Suppe, 1981: Stratigraphic record of plate interactions in the Coastal Range of eastern Taiwan. Memoir Geol. Soc. China, 4, 15-194.

Ho, C. S., 1986: A synthesis of the geologic evolution of Taiwan. Tectonophysics, 125: 1-16.

Ho, C. S., 1988: An introduction to the geology of Taiwan, 2nd ed., Central Geological Survey, The Ministry of Economic Affairs, Taipei, Taiwan, 192 pp. (in Chinese)

Hsu, S. K., and J.-C. Sibuet, 1995: Is Taiwan the result of arc-continent or arc-arc collision?, Earth Planet. Sci. Lett., 136, 315-324.

Lee, C. S., Jr. G.G. Shor, L. D. Bibce, R. S. Lu, and T. W. C. Hilde, 1980: Okinawa Trough: origin of a back-arc basin. Mar. Geol, 35, 219-241.

Lee, T. Y., and L.A. Lawver, 1994: Cenozoic plate reconstruction of the South China Sea 
region. Tectonophysics, 235, 149-180.

Liu, C. C., 1995: The Ilan plain and the southwestward extending Okinawa trough, J. Geol. Soc. China, 38, 229-242.

Liu, C. S., S. Y. Liu, G. S. Song, C. T. Shyu, H. S. Yu, L. Y. Chiaw, and C. Wang, 1996: Digital morphological file in the offshore region around Taiwan, Collection of $A b$ stracts of Annual Meeting of Geological Society of China, 420-425. (in Chinese)

Liu, C. S., S. Y. Liu, S. E. Lallemand, N. Lundberg, and D. Reed, 1998: Digital elevation model offshore Taiwan and its tectonic implications, TAO, 9, 705-738.

Seno, T., 1977: The instantaneous rotation vector of the Philippine Sea plate relative to the Eurasian plate. Tectonophysics, 42, 209-226.

Seno, T., S. Stein, and Gripp, A. E., 1993. A model for the motion of the Philippine Sea plate with NUVEL-1 and geological data. J. Geophys. Res., 98, 17941-17948.

Shyu, C. T., M. C. Chih, S. K. Hsu, C. Wang, and B. Karp, 1996: North Luzon arc: location and tectonic features from magnetic data of eastern Taiwan. TAO, 7, 535-548.

Sibuet, J.-C., B. Deffontaines, S. K. Hsu, N. Thareau, J.-P. Le Formal, C. S. Liu, and ACT party, 1998: Okinawa trough backarc basin: Early tectonic and magmatic evolution. $J$. Geophys. Res., 103, 30245-30267.

Suppe, J., 1984: Kinametic of arc-continental collision, flipping of subduction, and back-arc spreading near Taiwan. Memoir Geol. Soc. China, 6, 21-33.

Teng, L. S., 1990: Geotectonic evolution of late Cenozoic arc-continent collision. Tectonophysics, 183, 57-76.

Tsai, Y. B., T. L. Teng, J. M. Chiu, and H. L. Liu, 1977: Tectonic implications of the seismicity in Taiwan region. Memoir Geol. Soc. China, 2, 13-41.

Wang, C., 1982: Earthquakes caused by horizontal bending of the Philippine Sea plate near Taiwan. Tectonophysics, 88, T1-T6.

Wang, C., 1988: Horizontal lithospheric bending in eastern Taiwan region. Proc. of the second Taiwan Symposium on Geophysics, 343-349.

Wang, C., H. F. Huang, J. T. Shin, Y. L. Liu, Y. M. Wu, H. Y. Yen, and W. C. Liang, 1994: A study of distribution pattern of earthquakes occurred during 1991-1993 in the Taiwan region, Technical Report of Seismological Observation Center. Ministry of Communication(Taipei, Taiwan), 8-1, 243-271.(in Chinese)

Wang, C., T. H. Huang, I. C. Yen, S. L. Wang, and W. B. Cheng, 2000: Tectonic environment of the 1999 Chi-Chi earthquake in central Taiwan and its aftershock sequence. TAO, 11, 661-678.

Wang, C., and Y. M. Wu, 1991: Tectonic structure model of the Ryukyu subduction zone near the eastern coastline of Taiwan, Proc. of the third Taiwan Symposium on Geophysics, 447-457.

Wang, C., M. L. Yang, C. P. Chou, Y. C. Chang, and C. S. Lee, 2000: Westward extension of the Okinawa trough at its western end: Bathymetric and seismological evidences. TAO, 11, 459-480.

Yu, S. B., H. Y. Chen, and L. C. Kuo, 1997: Velocity field of GPS stations in the Taiwan area. Tectonophysics, 274, 41-59. 